\title{
PHENOTYPIC AND FUNCTIONAL SIMILARITIES BETWEEN 5-AZACYTIDINE-TREATED T CELLS AND A T CELL SUBSET IN PATIENTS WITH ACTIVE SYSTEMIC LUPUS ERYTHEMATOSUS
}

\author{
BRUCE C. RICHARDSON, JOHN R. STRAHLER, T. SCOTT PIVIROTTO, JAWAID QUDDUS, \\ GARRY E. BAYLISS, LAURA A. GROSS, KENNETH S. O'ROURKE, DANIEL POWERS, \\ SAMIR M. HANASH, and MARCIA A. JOHNSON
}

Objective. Antigen-specific CD4+ T cells treated with DNA methylation inhibitors become autoreactive, suggesting a novel mechanism for autoimmunity. To test whether this mechanism might be involved in systemic lupus erythematosus (SLE), phenotypic markers for the autoreactive cells were sought.

Methods. Cloned normal $T$ cells were treated with the DNA methylation inhibitor 5-azacytidine (5azaC) and studied for altered gene expression. $T$ cells from patients with active SLE were then studied for a similar change in gene expression, and cells expressing the marker were tested for autoreactivity.

Results. 5-azaC-treated normal $T$ cells had increased CD11a (leukocyte function-associated antigen 1a) expression relative to other membrane molecules. A $T$ cell subset with similar CD11a expression was found in patients with active SLE. This subset contained cells that spontaneously lysed autologous macrophages, with a specificity similar to that of 5-azaC-treated cells.

From the Departments of Internal Medicine, Pediatrics, and Human Genetics, University of Michigan, and the Ann Arbor Veterans Administration Hospital, Ann Arbor, Michigan.

Supported by PHS grants AI-25526 and AR-20557, and by a Veterans Administration Merit Review grant.

Bruce C. Richardson, MD, PhD: Department of Internal Medicine; John R. Strahler, PhD: Department of Pediatrics; T. Scott Pivirotto, MS: Department of Human Genetics; Jawaid Quddus, PhD: Department of Internal Medicine; Garry E. Bayliss, MD: Department of Internal Medicine; Laura A. Gross, MS: Department of Internal Medicine; Kenneth S. O'Rourke, MD: Department of Internal Medicine; Daniel Powers, MS: Department of Internal Medicine; Samir M. Hanash, MD, PhD: Department of Pediatrics; Marcia A. Johnson, MD, PhD: Department of Internal Medicine. Address reprint requests to Bruce $\mathrm{C}$. Richardson, MD, PhD, 4550 Kresge 1, Box 0531, Ann Arbor, MI 48109.

Submitted for publication March 21, 1991; accepted in revised form January 30, 1992.
Conclusion. The model of 5-azaC-induced autoreactivity may have relevance to SLE.

Antigen-specific CD4 $+\mathrm{T}$ cell clones respond to autologous macrophages (M $\varnothing$ ) without antigen, following treatment with DNA methylation inhibitors such as 5-azacytidine (5-azaC). The response is inhibited by monoclonal antibodies (MAb) against $\mathrm{CD} 3$ and class II major histocompatibility complex (MHC) determinants, and occurs with autologous but not allogeneic $\mathbf{M} \phi(1,2)$, suggesting that the cells are responding to autologous class II MHC determinants via a pathway involving the antigen/MHC receptor. Similar concentrations of 5-azaC alter gene expression in a wide range of cell types, including $T$ cells (3-5), and the autoreactivity may be caused by changes in the expression of as-yet-unidentified genes involved in $\mathrm{T}$ cell activation.

5-azaC-induced autoreactivity may have relevance to autoimmunity. Recent experiments have shown that murine $\mathrm{T}$ cells can become autoreactive following 5-azaC treatment, responding to and, intriguingly, lysing, syngeneic $\mathrm{M} \emptyset$. Adoptive transfer of murine 5-azaC-treated cells induces an immune complex glomerulonephritis and anti-DNA antibodies in nonirradiated syngeneic mice (6). These findings suggest a novel model for systemic lupus erythematosus (SLE), in which T cell DNA hypomethylation could alter expression of crucial genes, resulting in $T$ cell autoreactivity, and the autoreactive $T$ cells could then produce a lupus-like illness. Reports that lupusinducing drugs inhibit $T$ cell DNA methylation and induce autoreactivity (7) support this concept. Moreover, recent evidence indicates that $T$ cell DNA methylation is impaired in patients with active SLE (8). 
If DNA hypomethylation affects the same genes in 5-azaC-treated and lupus $\mathrm{T}$ cells, changes in gene expression and $\mathrm{T}$ cell function similar to those observed with 5-azaC treatment might occur in SLE. In the present study, a $T$ cell gene product altered by 5-azaC treatment was sought. $T$ cells from patients with active SLE were then examined for a similar change in gene expression, and $T$ cells bearing this marker were tested for the presence of autoreactivity similar to that found in 5-azaC-treated cells.

\section{PATIENTS AND METHODS}

Patient populations. Patients with rheumatoid arthritis (RA), SLE, systemic sclerosis (SSc), polymyositis (PM), multiple sclerosis (MS), gout, osteoarthritis (OA), and acute infections were referred from the University of Michigan Affiliated Hospitals and Clinics. Healthy controls were recruited by advertising. Informed consent was obtained from all subjects. RA, SLE, and SSc patients met the American College of Rheumatology (ACR) (formerly, the American Rheumatism Association) criteria for the respective diseases (9-11), and PM patients met the criteria proposed by Bohan and Peter (12). Lupus activity was assessed using the method of Barada et al (13), where a score of $0=$ no activity, $1+=$ mild disease, $2+=$ moderate disease but without central nervous system (CNS) or renal involvement, and 3+ = significant multisystem disease with CNS and/or renal involvement. RA activity was determined according to the ACR criteria for remission (14). The diagnosis of MS was based on clinical manifestations (15). Patients with OA exhibited radiographic evidence of the disease, and crystal identification was required for the diagnosis of gout. The group with acute infection included patients with gramnegative sepsis, multiple hepatic abscesses, multiple abdominal abscesses, osteomyelitis, tuberculosis, and septic bursitis.

T cell isolation and culture. Peripheral blood mononuclear cells (PBMC) were prepared from venous blood. Where indicated, $T$ cells were separated by rosetting with AET-bromide-treated sheep erythrocytes $(1,16,17)$. CD4+ cell lines were generated by treating PBMC with anti-CD8 (OKT8; Ortho Diagnostic Systems, Raritan, NJ) plus complement (Pel-Freez, Brown Deer, WI) followed by activation with phytohemagglutinin (PHA), and were maintained as long-term lines by weekly rechallenge with autologous irradiated (2,000R) PBMC plus anti-CD3 (Ortho) (2). Cloned, interleukin-2 (IL-2)-dependent, CD4+ tetanus toxoid (TT)reactive $T$ cell lines were generated and maintained in medium containing IL-2 (supernatant from the MLA-144 cell line) (18) and human $A B$ serum $(1,3)$. Where indicated, cultured cells were treated with 5 -azaC, hydroxyurea (both from Sigma, St. Louis, MO) or interferon- $\gamma$ (IFN $\gamma$; Genentech, South San Francisco, CA). The drugs were not removed after addition to culture. Proliferation assays were performed as previously described $(1,3)$. Where indicated, $20 \mu \mathrm{l}$ IL-2 (18) was also added to the cultures.
Monoclonal antibodies and flow cytometric analysis. Anti-CD2 (OKT11), anti-CD5 (OKT1), anti-CD4 (OKT4a), and anti-CD3 (OKT3) were purchased from Ortho Pharmaceuticals (Raritan, NJ). Anti-HLA-A,B,C was purchased from Cappel (Malvern, PA), and anti-CD45RO, anti-CD69, and rat anti-laminin were from AMAC (Westbrook, ME). WT31, specific for $T$ cell receptor $\alpha / \beta(\mathrm{TCR} \alpha / \beta)$, was purchased from Accurate Chemicals (Westbury, NY). AntiCD11a (TS $1 / 22$, an inhibitor of $T$ cell responses) (19), anti-CD54 (intercellular adhesion molecule 1 [ICAM-1]) (RR 1/1.1.1) (20), and anti-CD58 (leukocyte function-associated antigen 3 [LFA-3]) (TS 2/9.1.1) (19) were generous gifts from Dr. Tim Springer. Anti-CD11a MAb TA-1, which does not inhibit $\mathbf{T}$ cell responses (21), was donated by Dr. Tucker LeBien. Anti-CD44 (22) was purchased from Sigma. Cloned cells were stained with anti-CD2-RD1 (Coulter, Hialeah, FL), or WT31, anti-CD3, anti-CD5, anti-CD11a, anti-CD44, anti-CD45RO, anti-CD54, anti-CD58, or anti-CD69 and goat anti-mouse Ig-fluorescein isothiocyanate (GAM-FITC; Coulter), and then analyzed on an EPICS V or C or Coulter ELITE flow cytometer $(1,3)$. PBMC were stained with anti-CD2-RD1, anti-CD3-RD1, or anti-CD4-RD1 (Coulter) and anti-CD11a plus GAM-FITC. Negative controls included RD1 and FITC-conjugated mouse serum immunoglobulin, GAM-FITC alone, and a laminin-specific MAb isotype matched to TS $1 / 22$ plus GAM-FITC. For cell cycle analysis, cells were stained with propidium iodide (Sigma), using the method of Braylan et al (23).

Cytotoxicity assays. Autologous Mø killing was measured using a modification of the method described by Ottenhoff et al (24). PBMC (0.25-0.5 $\left.\times 10^{6}\right)$ were adhered to round-bottomed microtiter wells in $100 \mu \mathrm{RPMI} / 10 \% \mathrm{AB}$ serum for 1-2 hours, after which the nonadherent cells were removed. Approximately $10 \%$ of the cells were assumed to remain adherent (24). The adherent cells were labeled with 2 $\mu \mathrm{Ci}{ }^{51} \mathrm{Cr} /$ well (New England Nuclear, Boston, MA) for 3 hours, then washed. This labeling protocol typically gave $4,000-8,000$ counts per minute/well ${ }^{51} \mathrm{Cr}$ incorporation. In experiments using cells isolated by rosetting, $\mathrm{T}$ cells were added to the labeled $M \varnothing$ at $10 \times 10^{4}, 5 \times 10^{4}$, or $2.5 \times 10^{4}$ per well, in $200 \mu \mathrm{l} R \mathrm{RMI} / 10 \% \mathrm{AB}$ serum (final volume). When T cells were isolated by flow cytometry, the maximum number of $T$ cells depended on the number recovered.

Seventy-five-microliter aliquots were removed at 6 hours and 18 hours. At 18 hours the wells were completely aspirated and the remaining $M \varnothing$ were lysed with $100 \mu \mathrm{l} 1 \%$ NP40 in water, and ${ }^{51} \mathrm{Cr}$ was measured in the 6-hour and 18-hour supernatant aliquots and the NP40 lysate, using an LKB 1209 Rackbeta scintillation spectrometer. Percent ${ }^{51} \mathrm{Cr}$ release was calculated for each well, using the formula

Test supernatant $\mathrm{cpm}$ corrected for total volume of $200 \mu \mathrm{l}$

Test cpm + cpm in NP40 lysate 100

In most experiments, killing was near maximal at 6 hours, and maximum ${ }^{51} \mathrm{Cr}$ release occurred by 18 hours. Spontaneous ${ }^{51} \mathrm{Cr}$ release usually ranged from $20 \%$ to $55 \%$ at 18 hours. The results of quadruplicate experiments were averaged, and results were corrected for spontaneous release, using the following formula: 
$\frac{\text { Experimental release }- \text { spontaneous release }}{100-\text { spontaneous release }} \times 100$

Monoclonal antibodies against monomorphic determinants on class I (anti-HLA-A,B,C) or class II MHC molecules (9.49, as ascites; kindly donated by Dr. Robert F. Todd, III) (25), or to CD11a (TS $1 / 22$, as culture supernatant) were added where indicated.

Two-dimensional polyacrylamide gel electrophoresis. Cells to be studied by 2-dimensional polyacrylamide gel electrophoresis (2-D PAGE) were thoroughly washed to remove serum proteins, then used immediately or radioiodinated with ${ }^{125}$ I using the lactoperoxidase technique (26). First and second dimensions were run as described (27), and spots analyzed for position and intensity on a Masscomp image analyzer computer system (Biolmage, Ann Arbor, MI) using a 1,024 × 1,024-pixel format (160 $\mu /$ pixel) (28). To detect radioiodinated polypeptides, the gels were dried and sealed in light-tight cassettes with $\mathrm{X}$-ray film (XAR-5; Eastman-Kodak, Rochester, NY) and Cronex enhancing screens (DuPont, Wilmington, DE).

Immunoprecipitation and 1-D sodium dodecyl sulfatePAGE. To immunoprecipitate the TCR complex, a modification of the procedure of Weiss et al was used (29). Radioiodinated $\mathrm{T}$ cells were lysed in $0.5 \mathrm{ml}$ of lysis buffer

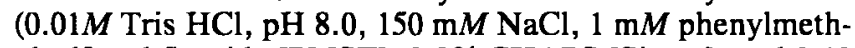
ylsulfonyl fluoride [PMSF], 0.3\% CHAPS [Sigma], and 0.10 $\mathrm{mg} / \mathrm{ml}$ soybean trypsin inhibitor [Sigma]). The lysed cells were centrifuged at $13,000 \mathrm{~g}$ for 5 minutes, and the supernatant was precleared with $100 \mu \mathrm{l}$ of formalin-fixed Staphylococcus aureus Cowan 1 (SAC) (10\% [weight/volume] in lysis buffer; The Enzyme Center, Malden, MA). One microgram of OKT3 (Ortho Pharmaceuticals) was added to the supernatant and incubated at $4^{\circ} \mathrm{C}$ for 1 hour, after which $100 \mu \mathrm{l}$ SAC was again added. The SAC was then washed 5 times with lysis buffer supplemented with $0.1 \%$ Triton $\mathrm{X}-100$. Bound material was eluted by boiling for 5 minutes in $100 \mu \mathrm{l}$ sodium dodecyl sulfate (SDS)-PAGE sample buffer, then fractionated by electrophoresis through $11 \%$ gels.

Immunoprecipitation of CD1 la was similar except for the following changes. The lysis buffer contained $5 \mathrm{mM}$ EDTA, $1 \mathrm{~m} M$ PMSF, $1 \%$ NP40, $10 \mathrm{~m} M$ sodium phosphate,

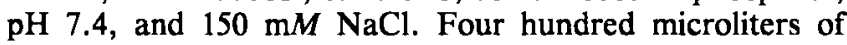
packed SAC was preincubated overnight with $240 \mu \mathrm{l}$ rabbit anti-rat IgG (Sigma) and washed 3 times with lysis buffer. Each aliquot of precleared solubilized cells was incubated with $5 \mu \mathrm{l}$ anti-CD11a ascites (diluted 1:10 in lysis buffer) overnight at $4^{\circ} \mathrm{C}$, after which the rabbit anti-rat-coated SAC was added; then the procedure described above was followed. Negative controls included purified rat IgG (Sigma) in place of the anti-CD11a.

RNA isolation and Northern blot analysis. RNA was isolated as described by MacDonald et al (30), and 10-20 $\mu \mathrm{g}$ (quantitated by ultraviolet [UV] spectrometry and ethidium bromide staining) was electrophoresed through a $1 \%$ agarose, 3\% formaldehyde gel and capillary blotted onto nylon membranes (Gene Screen Plus; New England Nuclear, Boston, MA). The membranes were hybridized with a ${ }^{32} \mathrm{P}-$ complementary DNA (cDNA) of the entire LFA- $1 \alpha$ coding sequence ( $\mathrm{pLAR}$ ), kindly donated by Dr. Tim Springer. Controls included a 2-kilobase Bam HI cDNA fragment of $\beta$-actin, donated by Dr. Gary Nabel, and a full-length CD2 cDNA (31). Autoradiograms were exposed for 1, 5, or more hours. Densitometry was performed using BioImage software. Images were digitized at $0.16 \mathrm{~mm} / \mathrm{pixel}$, with 256 possible values for each pixel. A reference step-wedge with steps of known optical density and length was also scanned, and bands are reported in units of optical density $/ \mathrm{mm}^{2}$.

Statistical analysis. Differences between the means of 2 groups were tested for significance using Student's $t$-test. Multiple groups were compared using analysis of variance, calculated with Systat (Evanston, IL) software.

\section{RESULTS}

Identification of gene products affected by 5-azaC. Two-dimensional PAGE analysis of 5-azaCtreated cells. A cloned, IL-2-dependent, CD4+, TTreactive $\mathrm{T}$ cell line, TT37L, was treated with $1 \mu M$ 5-azaC, and cells were removed at days $2,4,6$, and 8 for 2-D PAGE analysis of total cellular proteins or ${ }^{125}$ I-labeled membrane proteins. Previous studies showed that $1 \mu M 5$-azaC was the optimal level for inducing $\mathrm{T}$ cell autoreactivity, and that autoreactivity was usually observed on days $4-6$ after treatment $(1,2)$. Because higher concentrations of 5-azaC inhibit DNA synthesis, hydroxyurea was used to control for altered gene expression due to DNA synthesis inhibition. Hydroxyurea at $10 \mu M$ can alter $\mathrm{T}$ cell protein expression, but does not induce autoreactivity $(1,3)$. More than 1,000 spots were detected by silver staining, and 130 by autoradiography. No unique polypeptides appeared when 5-azaC-treated cells were compared with untreated and hydroxyurea-treated cells.

Effect of 5-azaC on the T cell receptor. Cloned, TT-reactive CD4+ T cells were treated with 0.5-4.0 $\mu M 5$-azaC and 6 days later, were stained with WT31, specific for TCR $\alpha / \beta$, or with anti-CD3. Consistent with previous reports (1), flow cytometric analysis revealed no reproducible changes in WT31 or CD3 expression at 5 -azaC concentrations that induced autoreactivity. To help exclude the possibility that additional receptor subunits were induced, TT37L cells were treated with $1 \mu M 5$-azaC and then 6 days later were vectorally labeled with ${ }^{125} \mathrm{I}$, and the TCR complex was immunoprecipitated using OKT3. One-dimensional SDSPAGE showed no qualitative or quantitative changes in the $\alpha$ or $\beta$ chains of the TCR or the 21 ( $\epsilon$ and $\delta$ )-kd and $25(\gamma)-\mathrm{kd} C D 3$ subunits, and no new polypeptides appeared.

Increased CD11 a expression after 5-azaC treatment. Flow cytometry was used to study the effect of 5 -azaC on other membrane molecules implicated in $\mathrm{T}$ 

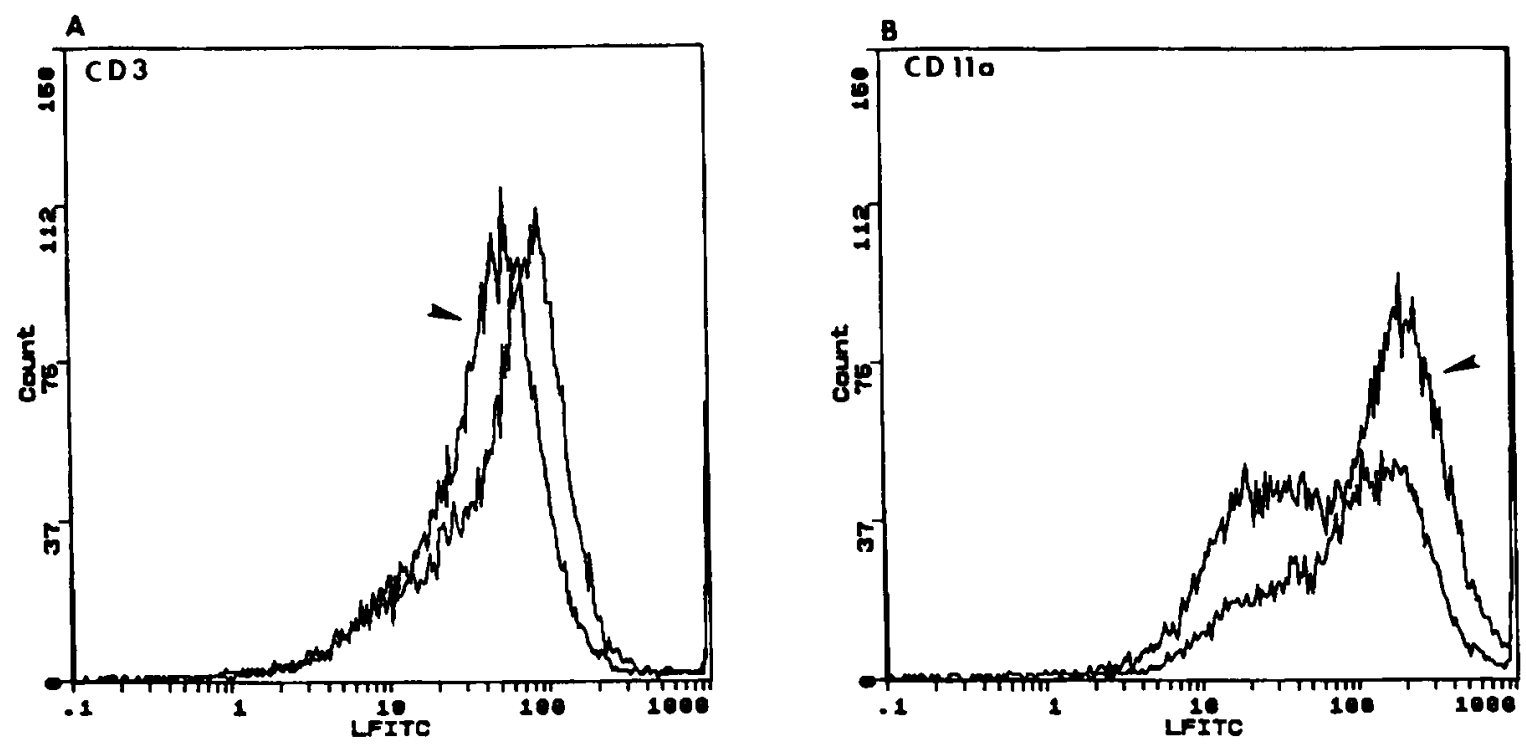

Figure 1. Increase in CD11a expression after treatment with 5-azacytidine (5-azaC). TT18X cells were treated with 5-azaC, and 6 days later, treated and untreated cells were washed, stained with anti-CD3 (A) or anti-CD11a (B) and goat anti-mouse Ig-fiuorescein isothiocyanate (FITC), and analyzed by flow cytometry. The x-axis represents log FITC fluorescence intensity (LFITC), in arbitrary units; the $y$-axis represents cell number. A, The CD3 mean cell fluorescence (MCF) is $\mathbf{4 7 . 4}$ for the untreated cells and $\mathbf{3 7 . 2}$ for the treated cells (arrowhead). B, The CDI la MCF is 52.9 for the untreated cells and 118 for the treated cells (arrowhead). To analyze shifts in staining intensity, the histogram of CD1 la MCF was divided at fluorescence intensity $=60$, and the MCF of the peaks lying between 0.1 and 60 and between 60 and 1,000 was determined, using ELITE software. For untreated cells these values were 19.2 and 157, and for treated cells the values were 22 and 197.

cell function, including CD2, CD5, CD11a, CD44, CD45RO, CD54, CD58, and CD69. CD1, CD3, CD4, CD8, CD29, and CD45RA were studied previously $(1,2)$. In experiments similar to those described above, either no changes or small decreases were seen in CD2, CD5, CD44, CD45RO, CD54, CD58, and CD69 expression. However, 5-azaC increased CD11a expression relative to that in untreated cells (Figure 1). This increase occurred on a subset of cells that initially expressed low amounts of LFA-1 (Figure 1B). The mean cell fluorescence (MCF) of the low expression peak in the untreated cells was 19.2, and the MCF of the new peak in the treated cells was 197, suggesting that the increase was approximately 10 -fold. However, expression did not change on all cells, and the average increase over all cells was approximately 2-fold (MCF 52.9 versus 118, untreated versus treated). Similar results were observed using 4 other TTreactive $\mathrm{T}$ cell lines, and in a total of 5 experiments on these 4 other distinct cloned lines, the average increase in CD11a expression was $67 \pm 16 \%$ (mean \pm SEM), with a range of 38-110\%. The variability and magnitude of the change in CD1 la expression reflects the instability of 5-azaC in aqueous solutions (32), the percentage of cells in the $S$ phase at the time of treatment $(3,4)$, and the fact that altered gene expression occurs in, at best, $50 \%$ of 5 -azaC-treated cells (4).

In contrast to 5-azaC, 1-100 $\mu M$ hydroxyurea did not significantly alter CD11a expression (mean \pm SEM $7 \pm 7 \%$ increase; $n=4$ ). The difference between the effects of 5 -azaC and those of hydroxyurea on LFA-1 expression was significant $(P<0.02)$. To further exclude the possibility that 5-azaC alters LFA-1 expression by inhibiting DNA synthesis, propidium iodide was used to examine cell cycling (23). No change was seen between untreated and 5-azaCtreated cells in the number of cells in the $\mathrm{G}_{0} \mathrm{G}_{1}(77.7 \pm$ $2.9 \%$ versus $79.6 \pm 2.1 \%), \mathrm{S}(10.2 \pm 1.7 \%$ versus 10.4 $\pm 2.2 \%)$, or $\mathrm{G}_{2} \mathrm{M}$ phase $(10.6 \pm 1.8 \%$ versus $9.9 \pm$ $1.4 \%$ ) (mean \pm SEM of 3 experiments). Kinetic analysis revealed that $\mathrm{CD} 11$ a expression usually began to increase 3 days after 5 -azaC treatment and was maximal by day 4 , correlating with autoreactivity $(1,2)$.

To confirm that 5-azaC increased CD11a expression, LFA-1 was immunoprecipitated from ${ }^{125} \mathrm{I}$ labeled TT45C cells with and without 5-azaC treatment. Figure 2 shows the SDS-PAGE analysis of LFA-1 immunoprecipitated from the same number of 
untreated cells or cells treated with $1 \mu M$ or $4 \mu M$ 5-azaC. In all preparations, anti-CD1 la precipitated a 170-kd band and a $95-\mathrm{kd}$ band, consistent with previous descriptions of the $\alpha$ and $\beta$ chains of LFA-1 (19). A 4- $\mu M$ concentration of 5-azaC, previously shown to be toxic and not to induce autoreactivity $(1,3)$, appeared to diminish the amount of LFA-1 on this cell line, while $1 \mu M$ of 5 -azaC caused an apparent increase in LFA-1 expression. No changes in the size of the $\alpha$ and $\beta$ chains were noted, and no cross-reactive molecules were identified.

Northern blot analysis was used to determine if

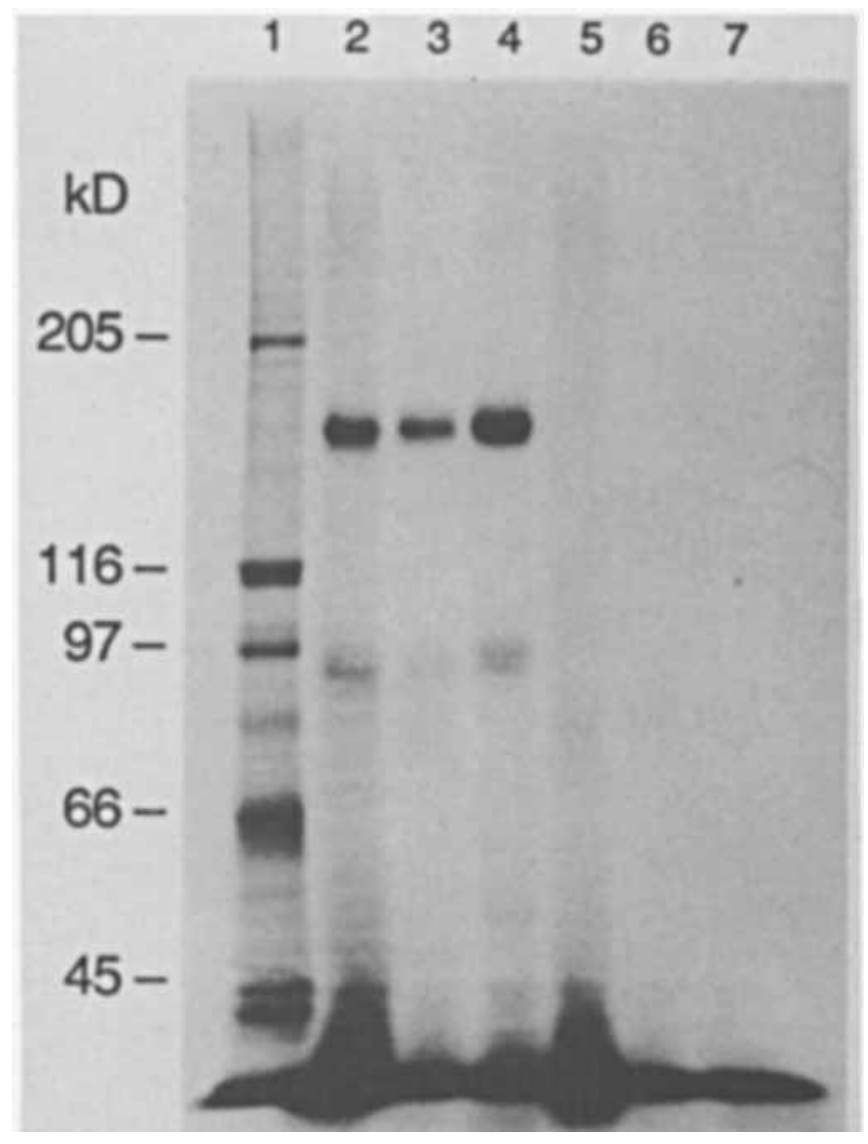

Figure 2. Immunoprecipitation of CD11a from 5-azacytidine (5azaC)-treated T cells. TT45C cells were treated with $1 \mu M$ or $4 \mu M$ 5 -azaC, and 6 days later, the cells were harvested and $10^{7}$ treated or untreated cells were surface labeled with ${ }^{125} \mathrm{I}$. Immunoprecipitation was performed using anti-CD11a ascites (lanes 2-4) or purified rat IgG (lanes 5-7). Lane 1 contains molecular weight markers. Immunoprecipitates from untreated cells are shown in lanes 2 and 5 , from cells treated with $4 \mu M$ 5-azaC in lanes 3 and 6 , and from cells treated with $1 \mu M$ 5-azaC in lanes 4 and 7. Densitometric analysis demonstrated that the optical density $/ \mathrm{mm}^{2}$ of the $\alpha$-chain bands was as follows: lane $2,9.5$; lane $3,5.8$; lane $4,13.3$.

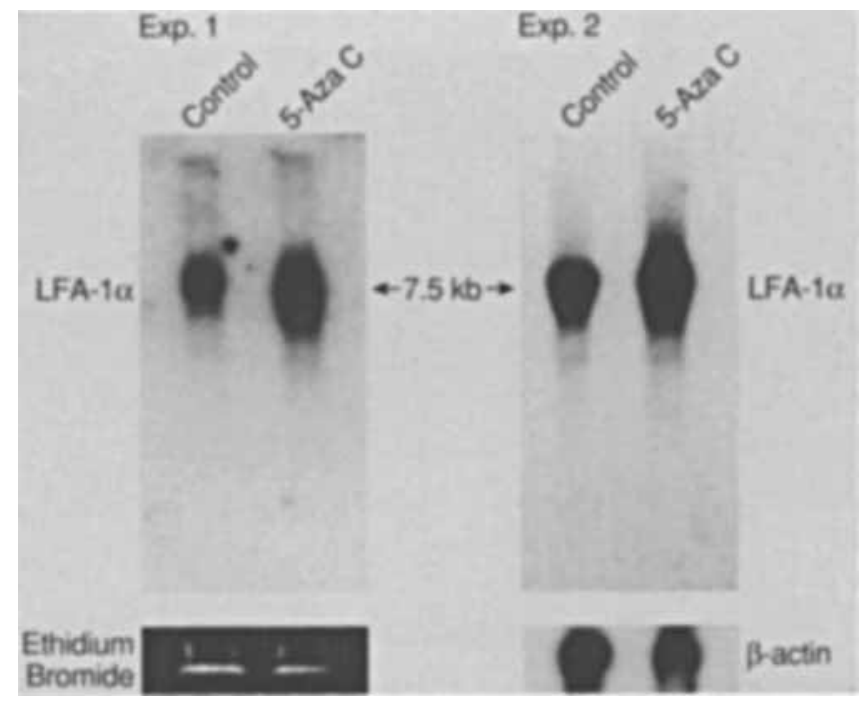

Figure 3. Northern blot analysis of leukocyte function-associated antigen $1 \alpha$ (LFA-1 $\alpha$ ) expression. RNA was isolated from untreated TT45C cells (control) or cells treated with 5-azacytidine (5-azaC). Concentration was assessed by ethidium bromide staining, and the purified RNA was electrophoresed through agar gels. Separated RNA was transferred to nylon filters and hybridized with a ${ }^{32} \mathrm{P}-$ LFA- $1 \alpha$ complementary DNA (cDNA). The blot shown in experiment $I$ is an 18-hour exposure, and the blot shown in experiment 2 is a 5-hour exposure. In experiment 1, total RNA was stained with ethidium bromide, and in experiment 2 , the blot was stripped and rehybridized with a ${ }^{32} \mathrm{P}-\beta$-actin $\mathrm{cDNA}$. Densitometric analysis of the autoradiograms demonstrated that the optical density $/ \mathrm{mm}^{2}$ of the LFA- $1 \alpha$ bands in experiment 1 was as follows: control 48, 5 -azaC-treated cells 86 . In experiment 2 , the values for the LFA-1 $\alpha$ bands were 77 and 109 (control and 5-azaC-treated, respectively), and similar values wert found for the $\beta$-actin bands (95.7 and 82.1).

5-azaC also increased LFA- $1 \alpha$ messenger RNA (mRNA). RNA was isolated from untreated and 5-azaC-treated TT45C cells, fractionated by agar gel electrophoresis, transferred to nylon filters, and hybridized with an LFA- $1 \alpha$ cDNA (Figure 3 ). In experiment 1, the amount of RNA applied to each lane in the gel was identical by UV spectroscopy, ethidium bromide staining of total RNA, and ethidium bromide staining of the $18 \mathrm{~S}$ ribosomal RNA (rRNA) bands (not shown). In experiment 2 , the blots were stripped and rehybridized with a $\beta$-actin cDNA. Densitometric analysis of the 2-D gels described above demonstrated that 5-azaC had no effect on $\beta$-actin expression. In 3 independent experiments, 5 -azaC treatment increased LFA- $1 \alpha$ expression relative to controls by a mean \pm SEM of $63 \pm 11 \%$ (range $42-79 \%)(P<0.05$ by univariate $t$-test for the mean), similar to the increase measured by cytofluorography. LFA- $1 \alpha$ mRNA also increased relative to $\beta$-actin, and additional experi- 

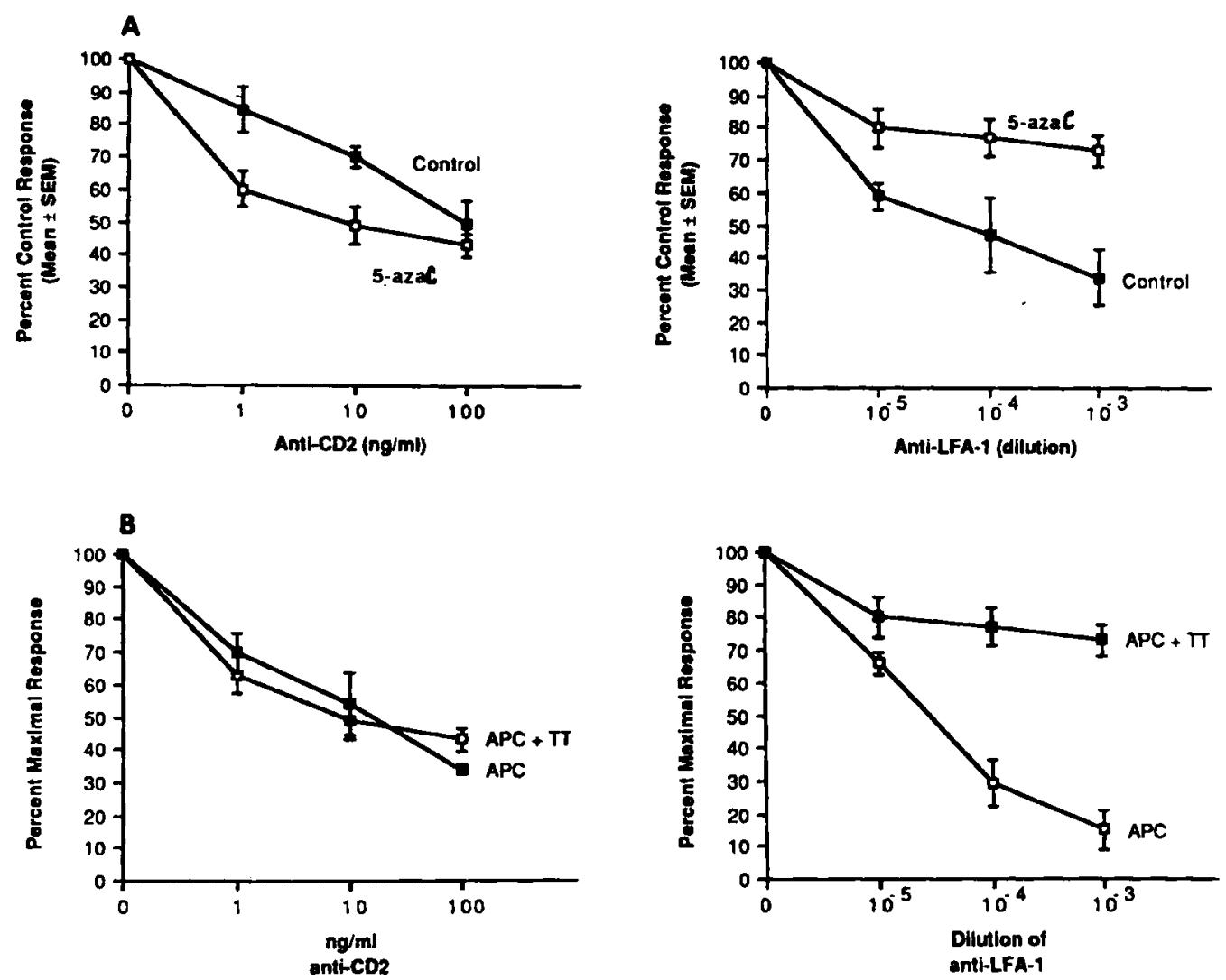

Figure 4. Effect of anti-CD1la on 5-azacytidine (5-azaC)-treated cells. A, Resistance of 5-azaC-treated cells to anti-CD1la inhibition. TT37L cells were treated with 5 -azaC or were left untreated (control). Six days later, the cells were washed, cultured for 18 hours without interleukin-2 or 5 -azaC, then challenged with $10^{5}$ irradiated autologous peripheral blood mononuclear cells as antigen-presenting cells (APC), and tetanus toxoid (TT) diluted 1:50. Anti-CD2 (left panel) and anti-CD11a (anti-leukocyte function-associated antigen I [anti-LFA-1]) (right panel) were added at the concentrations indicated, and proliferation was measured 48 hours later by ${ }^{3} \mathrm{H}$-thymidine incorporation. Results were calculated as the percentage of the response in control cultures without added monoclonal antibody (MAb), and represent the mean \pm SEM of quadruplicate determinations. The control response of untreated cells to APC + TT was $8,597 \pm 255 \mathrm{cpm}$ with a background of $949 \pm 180 \mathrm{cpm}$; the control response of 5 -azaC-treated cells to APC + TT was $37,686 \pm 2,952 \mathrm{cpm}$, with a background of $2,251 \pm 256 \mathrm{cpm}$. B, Inhibition of 5-azaC-induced autoreactivity, more than antigen reactivity, by anti-CD11a. TT37L cells were treated with 5-azaC, and 6 days later, challenged with irradiated autologous APC with or without TT, in the presence of anti-CD2 (left panel) or anti-CD1 la (right panel) at the concentrations indicated. Results are expressed as the mean \pm SEM of quadruplicate determinations, normalized to results in control cultures without added MAb. The control response to APC without TT was $16,182 \pm 1,942 \mathrm{cpm}$; the control response to APC + TT was $37,686 \pm 2,952 \mathrm{cpm}$.

ments showed that 5-azaC increased CDI1a mRNA expression by $102 \pm 18 \%$ (mean \pm SEM of 2 experiments) relative to $\mathrm{CD} 2$ mRNA. These results suggest that 5 -azaC increases LFA- $1 \alpha$ expression relative to total RNA, rRNA, $\beta$-actin, and CD2.

If 5 -azaC increases LFA-1 expression, more anti-LFA-1 should be required to inhibit activation of 5-azaC-treated cells than of untreated cells. 5-azaCtreated TT37L cells were challenged with autologous antigen-presenting cells (APC) and TT in the presence of anti-CD2 or anti-CD11a (Figure 4A). Anti-CD2 at $100 \mathrm{ng} / \mathrm{ml}$ inhibited the antigen response in treated and untreated cells equally, and no significant differences were observed at lower concentrations. In contrast, the antigen response of 5-azaC-treated cells was relatively resistant to anti-CD1 la inhibition. At a dilution of $1: 1,000$, the response of untreated cells was $34 \pm$ $8.5 \%$ of control, while the response of treated cells was $73 \pm 5 \%$ (mean \pm SEM of quadruplicate determinations) $(P<0.01)$. In the experiment shown, the 
proliferative response of 5 -azaC-treated cells was greater than the response of untreated cells. This variability has been seen in other experiments and is attributed to differences in the optimal number of APC required for activation of treated and untreated cells (1). For the antibody inhibition experiments, it was important to keep the number of APC constant. To test whether 5-azaC-treated cells were completely resistant to anti-CD11a inhibition, higher concentrations of anti-CD1la were also used. At a dilution of $1: 100$, anti-CD11a inhibited the antigen-induced response by $84 \pm 7 \%$ in 5 -azaC-treated cells, indicating that higher concentrations were inhibitory.

The effect of MAb against CDIla on antigen reactivity and on autoreactivity was compared in 5-azaC-treated cells. Treated TT37L cells were challenged with irradiated autologous APC with and without TT, in the presence of anti-CD2 or anti-CD11a (Figure 4B). Anti-CD2 inhibited the response to APC without TT (autoreactivity) and antigen reactivity to the same degree at all concentrations tested. In contrast, anti-CD1la inhibited autoreactivity to a much greater extent than antigen reactivity. At a dilution of 1:1,000, anti-CD11a inhibited the response to APC alone by $85 \pm 6 \%$, while inhibiting the antigen response by $27 \pm 5 \%$ (mean \pm SEM of quadruplicate determinations) $(P<0.001)$. The preferential inhibition of autoreactivity over antigen reactivity by anti-

Table 1. Effect of antibodies to $T$ cell surface molecules on autoreactivity and antigen reactivity*

\begin{tabular}{lccc}
\hline & \multicolumn{3}{c}{$\begin{array}{c}\text { Response, \% of } \\
\text { control }\end{array}$} \\
\cline { 2 - 3 } \multicolumn{1}{c}{ MAb (n) $\dagger$} & APC & APC + TT & $P \ddagger$ \\
\hline Anti-CD2, $100 \mathrm{ng} / \mathrm{ml}(3)$ & $35 \pm 5$ & $36 \pm 5$ & NS \\
Anti-CD11 1a, 1:1,000 (3) & $28 \pm 10$ & $82 \pm 9$ & $<0.02$ \\
Anti-CD54, 1:1,000 (3) & $12 \pm 7$ & $63 \pm 10$ & $<0.02$ \\
Anti-CD4, 100 ng/ml (3) & $100 \pm 1$ & $61 \pm 2$ & ND \\
Anti-HLA-A,B,C, 100 ng/ml (3) & $84 \pm 16$ & $90 \pm 5$ & NS \\
\hline
\end{tabular}

* TT37L was treated with 5-azacytidine and then 4-6 days later, cultured with monoclonal antibodies (MAb) and irradiated autologous antigen-presenting cells (APC), with or without tetanus toxoid (TT). Proliferation was measured 48 hours later. Results were calculated as the percentage of the response in control cultures set up without MAb, and represent the mean \pm SEM of 3 independent experiments, each performed in quadruplicate at different times. The mean \pm SEM value for the 3 control responses to APC alone was 8,597 $\pm 3,804 \mathrm{cpm}$ (range 4,290-16,182), and the mean \pm SEM value for the 3 control responses to APC + TT was $20,767 \pm 8,746$ cpm (range 8,464-37,686).

$\dagger$ Anti-CD1 la and anti-CD54 were used as ascites; the other MAb were used in purified form.

$\ddagger$ Response to APC versus response to APC + TT by Student's $t$-test. NS = not significant; ND $=$ not done.
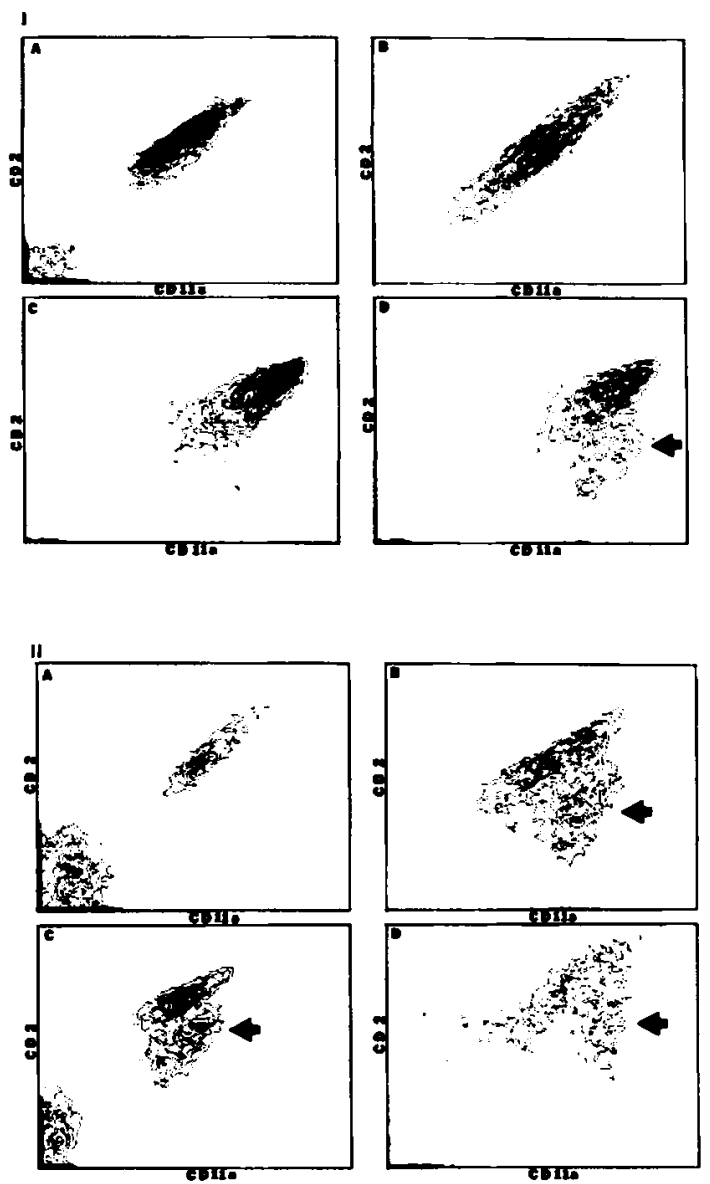

Figure 5. Comparison of CD1 la and CD2 expression in 5-azacytidine (5-azaC)-treated $\mathrm{T}$ cells and $\mathrm{T}$ cells from patients with systemic lupus erythematosus (SLE). I. Effect of 5-azaC and phytohemagglutinin (PHA) on CD2 and CD1 la expression. A, Peripheral blood mononuclear cells (PBMC) from a healthy donor were stained with anti-CD2-RD1 and anti-CD11a-fluorescein isothiocyanate (antiCD11a-FITC) as described in Patients and Methods, then analyzed by 2-color flow cytometry. B, PBMC from a healthy donor were activated with $0.5 \mu M$ PHA for 3 days, then stained and analyzed as in A. C, Interleukin-2-dependent, proliferating, polyclonal CD4+ cells were stained as in A. D. The same CD4 $+T$ cell line shown in $\mathbf{C}$ was treated with 5-azaC and 6 days later, stained as in A. Arrow indicates the subset with increased expression of CD1 la relative to CD2. II. CD2 and CD11a expression on T cells from patients with SLE. A, PBMC from a patient with inactive SLE, stained with anti-CD2-RD1 and anti-CD11a-FITC and analyzed as described in I. B, C, and D, PBMC from 3 different patients with active SLE, stained as in I. Arrows indicate the subset with increased expression of CD11a relative to $\mathrm{CD2}$.

CD11a at 1:1,000 was confirmed on a second cloned TT-reactive line, TT45C ( $65 \pm 3 \%$ autoreactivity, $10 \pm$ $11 \%$ antigen reactivity).

Table 1 summarizes the results of 3 independent experiments using the approach illustrated in Figure 

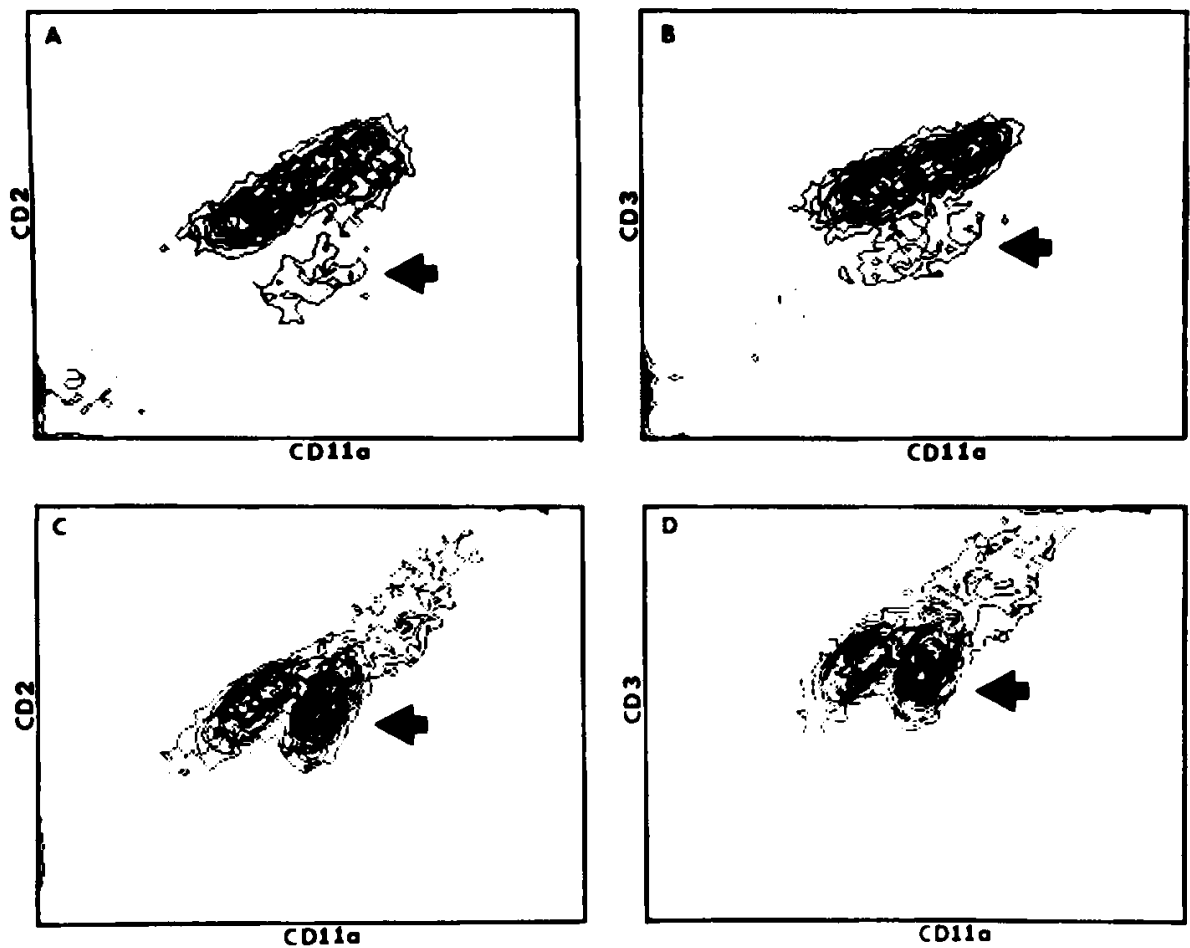

Figure 6. CD2, CD3, and CD11a expression on T cells from patients with RA and SLE. A, PBMC were isolated from a patient with RA and stained with anti-CD2-RDI and anti-CD11aFITC as in Figure 5. B, PBMC from the same donor as in A, stained with anti-CD3-RD1 and anti-CD11a-FITC. C, PBMC from a patient with active SLE, stained with anti-CD2 and antiCDIla-FITC. D, PBMC from the same donor as in $C$, stained with anti-CD3-RD1 and anti-CD11a-FITC. Arrows indicate cells with relatively increased expression of CDI1a. RA = rheumatoid arthritis; see Figure 5 for other definitions.

4B, comparing the effects of anti-CD2, anti-CD11a, anti-CD54, anti-CD4, and anti-HLA-A,B,C on autoreactivity and antigen reactivity in 5 -azaC-treated cells. Anti-CD2 inhibited antigen reactivity and autoreactivity equally, while anti-CD11a inhibited autoreactivity significantly more than antigen reactivity $(P<0.02)$. Antibodies to CD54, the ligand of CD1la (33), also inhibited autoreactivity better than TT reactivity $(P<0.02)$. Anti-CD4 antibodies (OKT4a), known to inhibit antigen-specific responses (34), failed to inhibit autoreactivity, but did inhibit antigen reactivity to a small degree (39\%) at $100 \mathrm{ng} / \mathrm{ml}$. Anti-HLA$A, B, C$ did not significantly inhibit either response. Anti-HLA-D was previously shown to inhibit the autoreactive response by $85-95 \%$ in cloned (1) and polyclonal (2) CD4+ cells, and was not restudied.

CD11a expression in patients with SLE. Effect of $T$ cell activation on CD1la and CD2 expression. Because $T$ cells may be activated in patients with autoimmune diseases (35), care was taken to confirm that $\mathrm{T}$ cell activation did not cause a similar increase in CD11a. CD1 1a expression was compared with expression of CD2, chosen as an internal standard, in freshly isolated and PHA-treated T cells. Figure 5IA shows freshly isolated $T$ cells from a healthy control stained with anti-CD2-RD1 and anti-CD11a-FITC. A range of $\mathrm{CD} 2$ and CD1 la expression is seen, but the markers are coordinately expressed. Figure 5IB shows $T$ cells treated with PHA for 3 days, then similarly stained. A broader range of CD2 and CD1 la expression is seen, but the 2 markers remain coordinately expressed. Identical results have been observed using cells from 5 healthy donors and 3 subjects with inactive SLE. Similar studies performed up to 9 days following PHA treatment demonstrated that at no time was there an increase in CD1la that was not accompanied by a corresponding increase in CD2.

Figure SIC shows a similarly stained IL-2dependent, proliferating CD4 $+\mathrm{T}$ cell line, and Figure SID shows the same CD4+ line treated with 5-azaC. 
5-azaC caused an increase in CD11a relative to CD2 in a portion of the cells (appearing as a subset to the right and below the cells with unaltered CD2 and CD11a expression).

Other investigators have reported that IFN $\gamma$ can alter CD1 1a expression on non-T cells (36), so the effect of IFN $\gamma$ on $T$ cell CD1 la expression was studied. No change in CD11a expression was observed using $10^{3}-10^{5}$ units $/ \mathrm{ml}$ of recombinant IFN $y$ in experiments similar to those shown in Figure 5I. These results suggest that a relative increase in CD11a is not a marker of $\mathrm{T}$ cell activation or IFN $\gamma$ release.

CDI la expression in SLE and RA. Evidence for the presence of a subset of cells with a relative increase in CD1 la was sought in patients with SLE. Figure SII shows PBMC from 1 subject with inactive SLE (Figure 5IIA) and 3 subjects with active SLE (Figures 5IIB, C, and D), stained with anti-CD2 and anti-CD1la as in Figure 5I. The patients with active SLE had a subset to the right and below the cells forming the diagonal pattern (compare with Figure 5IA), with some variability in the intensity of CD11a staining.

The new subset could arise from the population forming the diagonal either by an increase in CD11a or by a decrease in CD2. Therefore, CD11a expression was compared with $\mathrm{CD} 2$ and $\mathrm{CD} 3$ expression, in patients with SLE and RA (Figure 6). Each patient had a $T$ cell subset in which CD11a expression was increased relative to both $\mathrm{CD} 2$ and $\mathrm{CD} 3$. Similar results were seen in more than 10 patients. Similar studies indicated that CD1la was also increased relative to CD4 (data not shown). For convenience, the population of cells with a relative increase in CD11a will be referred to as $\mathrm{CD}_{11 \mathrm{a}^{+}}$, while the population with proportional expression of CDIla and control markers will be referred to as $C D 11 a^{0}$.

Figure 7A shows the percentage of cells in the $\mathrm{CD}_{11 \mathrm{a}^{+}}$subset in patients and controls. The subset was found in 25 of 49 patients with active or inactive SLE and 4 of 14 patients with RA, but in none of the patients with OA, gout, MS, or infection, or healthy controls. The $\mathrm{CD} 11 \mathrm{a}^{+}$subset was also found in 1 patient with an RA/SSc overlap and 1 with an SSc/PM overlap (see below), both with active disease, but not in 2 patients with active uncomplicated PM or 1 with chronic, stable SSc. An average of $20 \pm 2.8 \%$ of the T cells from SLE patients were in the $\mathrm{CD} 11 \mathrm{a}^{+}$subset (mean \pm SEM), and compared with the control populations, this was highly significant $(P=0.00005)$. An
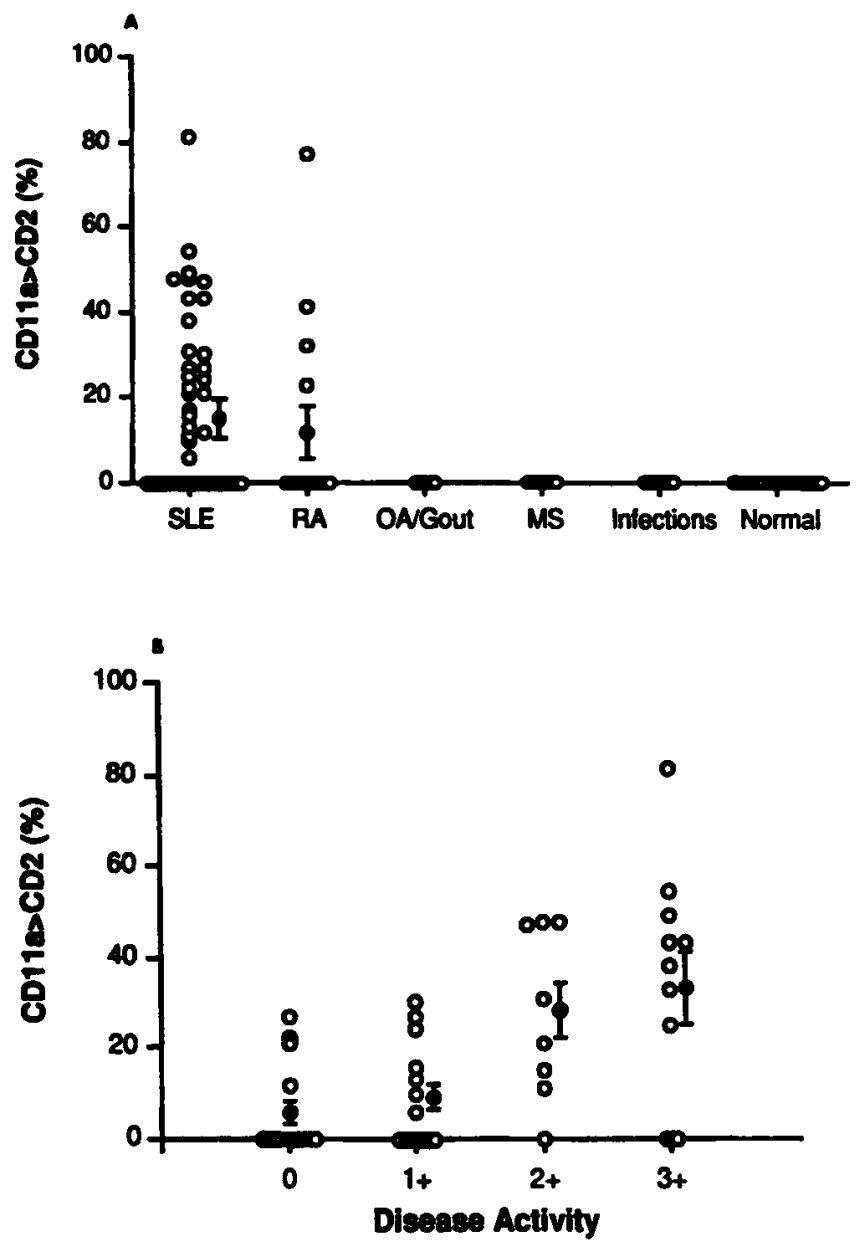

Figure 7. Percent $\mathrm{T}$ cells in the $\mathrm{CD} 1 \mathrm{a}^{+}$subset, in patients with autoimmune diseases and healthy controls. A, PBMC isolated from subjects with autoimmune diseases or normal controls were stained with anti-CD2-RD1 and anti-CD11a-FITC, and analyzed by flow cytometry as described in Figure 5 . The percent $T$ cells in the $\mathrm{CD}_{11}{ }^{+}$subset was determined by drawing bit maps around the

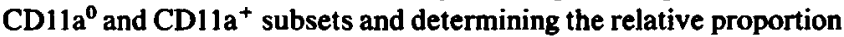
of cells in each population. Each open circle represents a single subject, with only 1 data point per subject. The closed circle with bars represents the mean \pm SEM of all data points within the indicated population. $B$, Relationship between percent $T$ cells in the $\mathrm{CD}_{11}{ }^{+}$subset and disease activity in the SLE patients shown in $\mathrm{A}$. Disease activity was assessed using the method of Barada et al (13). Each open circle represents a single patient, with one data point per patient. The closed circles with error bars represent the mean \pm SEM of the data points within the group. See Results for explanation of $\mathrm{CD}_{11 a^{\circ}}$ and $\mathrm{CDI1a}{ }^{+}$subsets. $\mathrm{RA}=$ rheumatoid arthritis; $\mathrm{OA}=$ osteoarthritis; $M S=$ multiple sclerosis. See Figure $S$ for other definitions.

average of $12 \pm 6.1 \%$ of $T$ cells from the RA population also fell into this subset $(P=0.023)$.

The correlation between the percentage of cells in the CD11a ${ }^{+}$subset and SLE disease activity was 
Table 2. Response of the $\mathrm{CD} 11 \mathrm{a}^{0}$ and $\mathrm{CD} 11 \mathrm{a}^{+}$subsets to autologous PBMC, with and without PHA*

\begin{tabular}{lcrc}
\hline & \multicolumn{2}{c}{ Response (cpm) } & \\
\cline { 2 - 3 } Stimulator (n) & \multicolumn{1}{c}{${\mathrm{CD} 11 \mathrm{a}^{0}}$} & \multicolumn{1}{c}{ CD11a } & $P \dagger$ \\
\hline PBMC (3) & $136 \pm 426$ & $994 \pm 229$ & NS \\
PBMC + PHA (3) & $71,356 \pm 8788$ & $16,443 \pm 685$ & $<0.01$ \\
\hline
\end{tabular}

* T cells from 3 patients with active systemic lupus erythematosus were separated into $\mathrm{CD} 1 \mathrm{a}^{0}$ or $\mathrm{CD} 1 \mathrm{a}^{+}$populations (see Results) by staining with anti-CD2-RD1 and the anti-CD1la monoclonal antibody TA-I plus goat anti-mouse Ig-fluorescein isothiocyanate, followed by sorting with a flow cytometer. Twenty thousand T cells were cultured with $10^{4}-10^{5}$ irradiated autologous peripheral blood mononuclear cells (PBMC), with or without $0.5 \mu \mathrm{g} / \mathrm{ml}$ phytohemagglutinin (PHA). Proliferation was measured by ${ }^{3} \mathrm{H}$-thymidine incorporation, as described in Patients and Methods. Values are the mean \pm SEM of the results from the 3 subjects; all determinations were performed in triplicate.

$\dagger$ Response with $C D 11 a^{0}$ population versus response with $\mathrm{CD} 11 \mathrm{a}^{+}$ population, by Student's $t$-test. NS $=$ not significant.

examined. Figure 7B shows the relationship of this subset to disease activity in the SLE patients depicted in Figure 7A. The majority of the 14 patients with inactive disease had few or no cells with increased CD11a. As disease activity increased, a greater percentage of subjects had the $\mathrm{CD}_{11 \mathrm{a}^{+}}$subset, and a greater percentage of cells were contained in the subset. Overall, 15 of 19 patients with $2-3+$ disease activity had cells expressing the $\mathrm{CD}_{11 \mathrm{a}^{+}}$phenotype. The likelihood of this distribution occurring by chance was 1 in $3.5 \times 10^{5}$. Serial studies in 6 patients demonstrated that the CD11a ${ }^{+}$subset disappeared within as few as 2-3 weeks of treatment (results not shown).

Functional characterization of the $C D 11 a^{+}$ subset. The interaction of the $\mathrm{CD} 1 \mathrm{la}^{+}$subset with autologous APC was studied using proliferation and cytotoxicity assays. PBMC from 3 patients with active SLE and a CD11a ${ }^{+}$subset were stained as above, but using the anti-CD11a MAb TA-1, which does not inhibit $T$ cell function (21), in place of TS $1 / 22$. The CD $11 a^{0}$ and CD11a ${ }^{+}$subsets were separated by flow cytometry, and each subset was challenged with autologous irradiated PBMC, with and without PHA (Table 2). Neither subset demonstrated a significant proliferative response to PBMC alone. The $\mathrm{CD} 11 \mathrm{a}^{0}$ subset responded vigorously to autologous PBMC plus PHA, while the $\mathrm{CD}_{11 \mathrm{a}^{+}}$subset, containing the same number of $T$ cells, was significantly less responsive to stimulation under the same conditions $(P<0.01)$.

To exclude the possibility that the $C D 11 a^{0}$ subset was required for IL-2 synthesis, the proliferation assays were performed with and without exoge- nous IL-2. Despite the addition of IL-2, the CD11a+ subset remained hyporesponsive to PHA, compared with the CD11a ${ }^{0}$ subset (mean \pm SEM 15,772 $\pm 12,991$ cpm versus $60,291 \pm 23,957 \mathrm{cpm}$ ). The reason for the decreased PHA response in the $\mathrm{CD}_{11 \mathrm{a}^{+}}$subset was not further addressed, but the results suggest that proliferation assays may not reliably measure an autoreactive response in this subset.

The isolated subsets were then tested for cytotoxicity, using ${ }^{51} \mathrm{Cr}$-labeled autologous $\mathrm{M} \emptyset$ as targets (Figure 8A). Autologous $\mathrm{M} \phi$ cultured with $\mathrm{CD}_{11 \mathrm{a}^{0}}$ cells released $12 \pm 3 \%$ of the ${ }^{51} \mathrm{Cr}$ label (mean $\pm \mathrm{SEM}$ of maximum release from the 6 patients). In contrast, cells isolated from the $\mathrm{CD} 11 \mathrm{a}^{+}$subset lysed autologous $M \emptyset$ without added antigen or lectin. The mean \pm SEM killing by the $\mathrm{CD}_{11 \mathrm{a}^{+}}$subset was $46 \pm 6 \%$, with a range of $30-69 \%$, significantly more than was seen with the $\mathrm{CD} 1 \mathrm{aa}^{0}$ subset $(P<0.005)$. In these experiments, the number of $T$ cells added to each killing assay was dependent on the number isolated by flow cytometry, so the variability in killing between patients may have been due to differences in the numbers of $T$ cells used. Serial studies were performed in 3 subjects with cytotoxic $\mathrm{CD} 11 \mathrm{a}^{+}$cells. Following treatment, the $\mathrm{CD} 1 \mathrm{la}^{+}$subset disappeared, and no killing above background ( $0 \%$ in all 3 ) was found in the remaining $C D 11 a^{0}$ cells.

To exclude the possibility that cytotoxicity was a result of the staining and sorting, $T$ cells were isolated by rosetting from subjects with and without the $\mathrm{CD}_{11 \mathrm{a}^{+}}$subset, and tested for autologous $\mathrm{M} \emptyset$ killing. In 5 additional SLE patients with the CD1 1a ${ }^{+}$ subset, the average autologous $M \emptyset$ killing was $46 \pm$ 7\%. As controls, $\mathrm{T}$ cells were isolated from 7 subjects lacking the $\mathrm{CD} 1 \mathrm{la}^{+}$subset, including 2 with inactive lupus. The average of the maximum cytotoxicity from the 7 control subjects $(8 \pm 4 \%)$ was comparable with that observed using the purified $\mathrm{CD} 11 \mathrm{a}^{0}$ subset $(12 \pm$ $3 \%$; see above). Neither of the 2 subjects with inactive lupus in the control group demonstrated significant $\mathbf{M} \emptyset$ killing above spontaneous release. The difference in cytotoxicity between the patients with active lupus and the control subjects was significant $(P<0.005)$.

5-azaC-autoreactive responses were inhibited by MAb to LFA-1 and to class II, but not class I, MHC determinants, and were specific for autologous M $\varnothing$ $(1,2) . \mathrm{CD}_{11 \mathrm{a}^{+}}$cells were tested for sensitivity to the same MAb and specificity for autologous $M \phi$. Since only limited numbers of $T$ cells could be obtained by flow cytometry, $T$ cells isolated by rosetting were used. Figure 8B shows the results of experiments in 

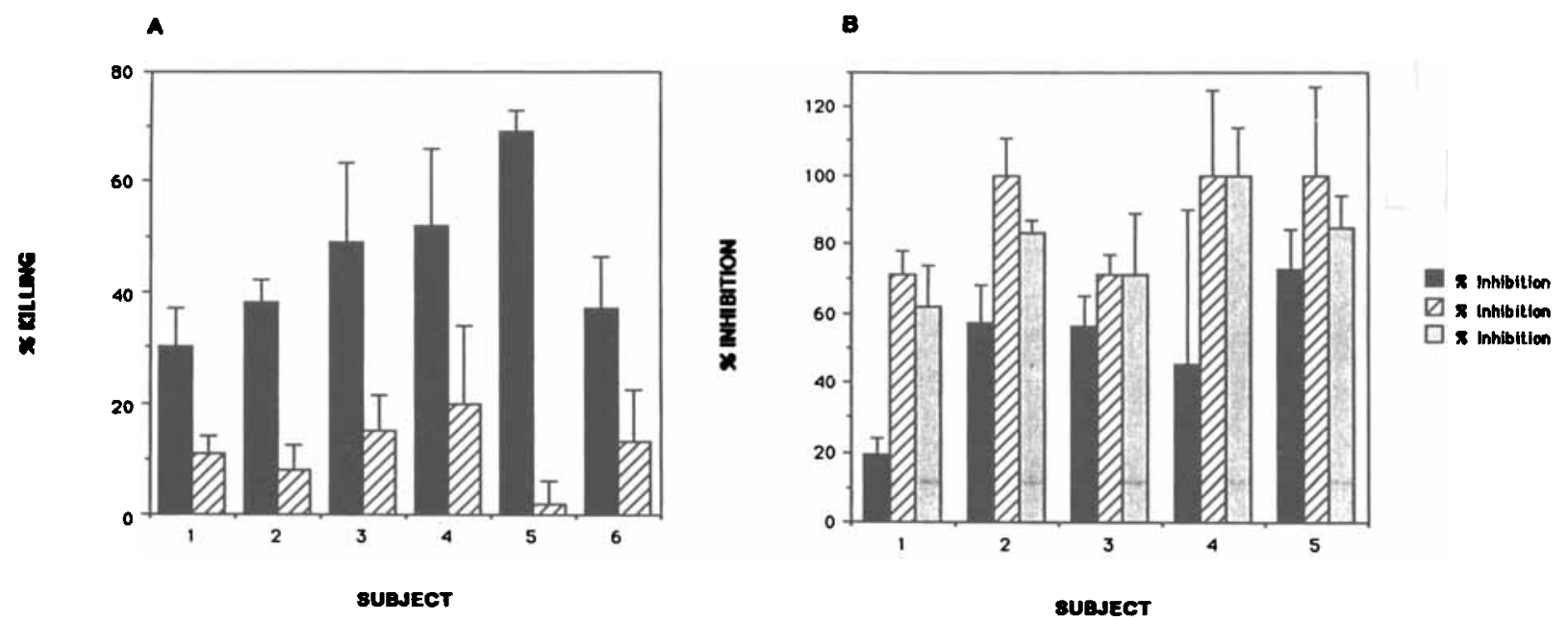

Figure 8. Killing of autologous $M \emptyset$ by $\mathrm{T}$ cells from the $\mathrm{CD} 1 \mathrm{la}^{+}$subset. A, Autologous $\mathrm{M} \emptyset$ killing was determined in 4 patients with SLE (subjects 1-4), 1 with an RA/SSc overlap syndrome (subject 5), and 1 with an SSc/PM overlap (subject 6). T cells were isolated from the $\mathrm{CD} 11 \mathrm{a}^{0}$ subset (hatched bars) and the CD11 $\mathrm{a}^{+}$subset (solid bars) by staining with anti-CD2-RD1 and anti-CD11a-FITC (TA-1) and sorting with a flow cytometer, and were then cultured with ${ }^{51} \mathrm{Cr}$-labeled autologous M $\varnothing$ as described in Patients and Methods. The maximum number of $T$ cells added to each well depended on the number obtained by sorting, and ranged from $2 \times 10^{4}$ to $10 \times 10^{4}$. For each subject equal numbers of cells from each subset were used. Three $\log _{2}$ dilutions of the $T$ cells were used for each subject, and all assays were performed in quadruplicate. Results are presented as the mean and SEM of the $T$ cell concentration, giving maximum killing. B, Inhibition of autologous Mø killing by MAb against CD11a and MHC determinants. T cells were isolated from 4 patients with active SLE and 1 with an SSc/PM overlap (subject 5), by rosetting with sheep erythrocytes. T cells $\left(10 \times 10^{4}\right)$ were then cultured with ${ }^{51} \mathrm{Cr}$-labeled autologous $\mathrm{M} \phi$, with or without MAb against class I MHC (solid bars), class II MHC (hatched bars), or CDI la (leukocyte function-associated antigen 1) (shaded bars) determinants. Macrophage killing was $42 \%$ in $\mathrm{T}$ cells from subject $1,60 \%$ in subject $2,55 \%$ in subject $3,22 \%$ in subject 4 , and $33 \%$ in subject 5. Anti-CD1 la was used as culture supernatant diluted 1:10-1:1000, anti-class II MHC was used as ascites diluted 1:10 $3{ }^{3}-1: 10^{6}$, and anti-class I MHC was used as purified protein at $1-100 \mathrm{ng} / \mathrm{ml}$. Results are presented as the mean and SEM of quadruplicate determinations at the concentration giving maximum inhibition, and represent the percent inhibition of total M killing, determined in the absence of MAb. See Results for explanation of $C D 11 a^{0}$ and $C D 11 a^{+}$subsets. $M \emptyset=$ macrophages; $R A=$ rheumatoid arthritis; SSc = systemic sclerosis; $\mathrm{PM}=$ polymyositis; $\mathrm{MHC}=$ major histocompatibility complex. See Figure 5 for other definitions.

which $\mathrm{T}$ cell killing of autologous $\mathrm{M} \varnothing$ was inhibited with the indicated MAb, using donors 3 and 6 shown in Figure 8A, and 3 other SLE patients with the CD11 $\mathrm{a}^{+}$ subset. Antibodies to class I MHC determinants inhibited killing $(50 \pm 9 \%$, mean \pm SEM of maximal inhibition from the 5 subjects), but were significantly less effective than MAb to class II determinants (88 \pm $7 \%)(P<0.02)$. Anti-CD1 la also inhibited killing $(80 \pm$ $7 \%$ ). TA-1 ascites was used at dilutions identical to those used for the anti-class II MHC MAb, and no inhibition was observed. To test whether M $\varnothing$ killing was specific for autologous $M \phi$, graded numbers of $T$ cells isolated from 4 of the subjects shown in Figure 8B were cultured as above, with ${ }^{51} \mathrm{Cr}$-labeled autologous $\mathrm{M} \phi$ or $\mathrm{M} \phi$ isolated from unrelated healthy donors. The $\mathrm{T}$ cells lysed autologous, but not allogeneic, $\mathrm{M} \varnothing(41 \pm$ $8 \%$ versus $7 \pm 5 \%$, mean \pm SEM of maximum lysis), suggesting specificity for autologous cells. In addition, no killing was observed when $\mathrm{T}$ cells from 3 SLE patients were incubated with $M \varnothing$ from other SLE patients.

\section{DISCUSSION}

One goal of the present study was to identify a marker for 5-azaC-treated cells. Studies using 2-dimensional PAGE analysis of total cellular proteins and cell membrane polypeptides revealed no qualitative changes induced by 5 -azaC, although small quantitative changes may have occurred and not been detected. This suggests that the effect of 5 -azaC on $T$ cells is subtle compared with its effects on fibroblasts (37). Flow cytometric comparison of CD3 and WT31 and immunoprecipitation with anti-CD3 revealed no detectable changes in the TCR. However, subtle changes in the $\mathrm{CD} 3$ subunits may have occurred, and not been detected with this approach. Changes in the expression of CD1, CD2, CD4, CD5, CD8, CD11a, 
CD29, CD44, CD45RA, CD45RO, CD54, CD58, and CD69 were sought in this and other studies $(1,2)$, using flow cytometric analysis. The only significant change was an increase in CDIla, confirmed by MAb inhibition studies, immunoprecipitation, and Northern blot analysis.

The increase occurred on a subset of the cells, and appeared to be approximately 10 -fold. 5-azacytidine inhibits DNA methylation only in S-phase cells (4), and is irreversibly converted to guanylribosylurea in aqueous media (32). Under optimal conditions, $50 \%$ of the cells will become hypomethylated (4), and fewer will become hypomethylated if the number of cells in the $S$ phase is low and hydrolysis is rapid. This is consistent with the results found in our study. Since not all cells changed expression, the average increase over all cells was approximately 2 -fold. Increases of similar magnitude were seen using Northern blot analysis. It is unlikely that this increase is due to activation, since PHA treatment increased CD1 la and CD2 together, as reported by Sanders et al (38). The increase in CD1la may be due to inhibition of DNA methylation, since hydroxyurea, a DNA synthesis inhibitor which does not inhibit DNA methylation (39), did not affect CD1la expression. Changes in expression of other gene products probably also occur, but these remain to be identified. The functional significance of the increased LFA-1 expression is unknown.

5 -azacytidine autoreactivity was inhibited by MAb against CD1 1a and CD54, suggesting that these molecules are important for the autoreactive response. Interestingly, the response to APC plus antigen required significantly more anti-CD11a for inhibition than did the response to APC alone. This is consistent with recent reports demonstrating a crucial role for CD11a/CD54 interactions in responses where the amount of the stimulating molecule is limiting or the interaction between the receptor and the class II MHC molecules is of low affinity (40). The interaction of the TCR with class II determinants alone should be of lower affinity than the interaction with class II MHC plus TT, and may require greater stabilization by LFA-1/ICAM-1 binding. This suggests that the increase in LFA-1 might contribute to autoreactivity. Anti-CD4 slightly inhibited the antigen response, but not the autoreactive response. The reason for this is not clear, but the finding was reproducible, and may reflect a difference in the role of CD4 between the autoreactive and antigen-reactive responses. AntiCD3 was previously shown to be a potent inhibitor of both auto- and antigen reactivity (1), and was not restudied.

Evidence for increased CD1 la expression on T cells from SLE patients and controls was sought. T cell activation and IFN $\gamma$ were excluded as causes for this marker. Other signals may increase CD1 la relative to other markers, but these remain to be identified. Patients with SLE, and a few patients with RA and other autoimmune diseases, were found to have a $\mathrm{T}$ cell subset with relatively more CD11a than CD2, CD3, and CD4. The CD11a ${ }^{+}$phenotype could be due to increased CD1la expression or a coordinate decrease in CD2, CD3, and CD4 expression. A coordinate decrease in these markers has not been described, so it seems more likely that CD1la expression is increased. Furthermore, the variability in CD1la expression between patients indicates that CD11a expression changes, and the other markers do not.

In a majority of the SLE patients, a strong correlation was found between the number of cells in the $\mathrm{CD} 11 \mathrm{a}^{+}$subset and disease activity. Some subjects with clinically inactive disease had a small percentage of cells in the CD11a+ ${ }^{+}$subset. It is possible that these subjects could have had serologic evidence of active disease, since this was not sought. Medications such as low-dose corticosteroids or nonsteroidal antiinflammatory agents, received by the majority of these subjects, could also have masked minor manifestations of disease activity. Four of 18 subjects with $2-3+$ active disease lacked evidence for the subset, suggesting exceptions to the relationship between the subset and disease activity. However, these subjects were already under treatment for their disease, and it is possible that the subset had disappeared before the samples were taken. Alternatively, there may be a subset of SLE patients who lack the CD11a ${ }^{+}$subset, suggesting alternative mechanisms contributing to lupus-like illnesses.

The origin of the $\mathrm{CD} 11 \mathrm{a}^{+}$subset is unclear. One possibility is that a relative increase in CD11a is an unusual activation marker on a $T$ cell subset, or a response to an unidentified lymphokine. This seems unlikely, because PHA-activated and IFN $\gamma$-treated cells did not display this marker, and patients with active infections did not have this subset. A second possibility is that the $\mathrm{CD}_{11 \mathrm{a}^{+}}$subset is normally present in subthreshold numbers, and is expanded in active SLE. This also seems unlikely, since up to $80 \%$ of circulating $T$ cells may express this change, and the subset can disappear in less than a month with treatment. However, lymphocyte trafficking, rapid subset 
expansion, or killing of $T$ cells could account for the shifts. A third possibility is that the $\mathrm{CD} 1 \mathrm{a}^{+}$subset arises from antigen-specific cells by a mechanism similar to that occurring in 5-azaC-treated cells.

Since the $\mathrm{CD}_{11 \mathrm{a}^{+}}$subset phenotypically resembles 5-azaC-treated $\mathrm{T}$ cells, responsiveness to autologous $\mathrm{M} \phi$ was studied. In contrast to 5-azaC-treated cells, the $\mathrm{CD}_{11 \mathrm{a}^{+}}$subset did not proliferate in response to autologous APC. However, the proliferative response to PHA was markedly diminished in the $\mathrm{CD} \mathrm{la}^{+}$subset, suggesting that proliferation assays may not be reliable tests of reactivity in this subset. This finding also suggests that the subset may be difficult to isolate using conventional IL-2-dependent cloning techniques. Others have noted that $T$ cells from patients with active SLE respond poorly to PHA stimulation despite addition of IL-2 (41), and it is possible that the CD11a ${ }^{+}$subset includes the cells that are refractory to stimulation. In RA, there is an inverse correlation between $T$ cells bearing activation markers and specific $\mathrm{T}$ cell proliferative responses (42), and recently activated $T$ cells can be refractory to restimulation, as measured by proliferation assays (43). If cells in the CD11a ${ }^{+}$subset were activated in vivo, they could be refractory to restimulation in vitro. Studies of activation markers on the $\mathrm{CDI1 \textrm {a } ^ { + }}$ subset, using 3-color analysis, will be necessary to test this possibility.

Numerous recent reports demonstrate that CD4+ cells may selectively lyse stimulating $M \phi$, and this phenomenon is commonly observed with cloned $\mathrm{T}$ cells (44-47). Experiments from our group have confirmed that cells treated with 5 -azaC will lyse syngeneic M $\varnothing$ without antigen (6). Since T cell proliferation could not be used to study the CD1 $\mathrm{a}^{+}$subset, autologous $\mathrm{M} \phi$ killing was measured. $\mathrm{CD} 11 \mathrm{a}^{+}$, but not $\mathrm{CD} 1 \mathrm{a}^{0}$, cells lysed autologous M $\phi$. The subjects studied included 2 with overlap syndromes. The cytotoxic cells isolated from these 2 subjects demonstrate that similar cells may occur in autoimmune rheumatic diseases other than SLE.

Whole $T$ cell populations from SLE patients with the $\mathrm{CD} 1 \mathrm{a}^{+}$subset also killed autologous $\mathrm{M} \emptyset$. The killing by unfractionated $\mathrm{T}$ cells is somewhat surprising, since an earlier investigation characterizing autocytotoxic $\mathrm{T}$ cells indicated that suppressor cells diminish the killing response, making killing assays unreliable without the use of limiting dilution techniques (48). However, it is possible that the suppressor defect attributed to SLE (49) permits detection of killing in whole $\mathrm{T}$ cell populations. Cytolysis was specific for autologous $M \varnothing$ and was almost completely inhibited with MAb against class II MHC determinants and LFA-1. T cells from lupus patients did not lyse $M \varnothing$ from other lupus patients, providing evidence against an SLE-specific M $\varnothing$ abnormality.

It is possible that the cytotoxic $T$ cells interact with target cells through unique structures, such as MHC molecules. Careful studies with MHC-typed donors will be required to establish the MHC restriction of this response. Whether the cells are responding to autologous MHC determinants such as 5-azaCtreated cells, or to an unidentified antigen presented by the $\mathbf{M} \emptyset$, remains to be determined. Since cytolysis was inhibited with anti-class II MAb, the cytotoxic cells may be CD4+. Monoclonal antibodies to class I determinants also inhibited killing, though to a lesser degree, suggesting a role for CD8+ cells as well. This is consistent with recent reports that CD8+ cells participate in at least some of the immune abnormalities in SLE (50). Again, 3-color flow cytometric analysis will be required to further characterize the cells in the $\mathrm{CD} 11 \mathrm{a}^{+}$subset.

It is possible that the $\mathrm{CD} 1 \mathrm{Ia}^{+}$subset contributes to the pathogenesis of SLE. Patients with active SLE have impaired immune complex clearance (51), and $T$ cells that kill autologous $M \varnothing$ could impair immune complex clearance. In addition, it has recently been shown that $T$ cells from lupus patients are required for the $B$ cell activation characteristic of lupus (50). In humans with the appropriate genetic makeup (52), perhaps the release of subcellular components from the lysed $M \varnothing$, together with "helper signals" from $T$ cells in the spleen or lymph nodes, stimulates production of the autoantibodies. Since 5-azaC-treated CD4+ cells can be activated by autologous B cells to secrete B cell differentiation factors (2), the $\mathrm{CD} 1 \mathrm{Ia}^{+}$cells may participate in the $\mathrm{B}$ cell activation. This is consistent with our observation that 5 -azaC-treated CD4 + cells induce immune complex deposition and autoantibodies in mice (6).

In contrast to the induction of lupus-like disease in mice by 5-azaC-treated $\mathrm{T}$ cells, Yoshida et al have reported that 5-azaC diminishes the massive lymphadenopathy and lupus-like syndrome which spontaneously develop in MRL-lpr mice (53). However, those authors demonstrated no such effect on BXSB mice, another strain that spontaneously develops lupus. It is likely, as Yoshida et al point out, that the beneficial effect of 5-azaC in MRL-lpr mice may be due to an inhibitory effect of 5-azaC on lymphoproliferation (53). 
This is consistent with the known effect of 5-azaC on DNA synthesis (39).

In summary, the increase in CD11a, the pattern of MAb inhibition, and the reactivity with autologous $M \emptyset$ are similar in $\mathrm{CD} 1 \mathrm{la}^{+}$cells and 5-azaC-treated cells $(1,2,6)$. The similarity in phenotype and function between the $\mathrm{CD} 1 \mathrm{a}^{+}$subset in SLE $\mathrm{T}$ cells and 5-azaC-treated $\mathrm{T}$ cells suggests that similar mechanisms could be involved in 5-azaC-induced and SLEassociated $\mathrm{T}$ cell autoreactivity.

\section{ACKNOWLEDGMENTS}

The authors thank Camille Wilkinson, Clare Rogers, Kris Weber, Chris Hier, Forrest Hooper, and Marc Toth for expert technical assistance; Ruth Douglas and Michele Thompson for expert secretarial assistance; and Dr. G. William Jourdian for many helpful discussions and encouragement. Thanks are also given to Drs. James Baker, G. William Jourdian, Robert F. Todd III, and Kevin Cooper for critical review of the manuscript. Special thanks are due Drs. Tim Springer, Tucker LeBien, and Robert F. Todd III for their generous contribution of anti-CD11a, anti-CD54, anti-CD58, and anti-HLA-D monoclonal antibodies. Thanks also to Dr. Tim Springer for his generous contribution of LFA- $1 \alpha$ cDNA

\section{REFERENCES}

1. Richardson BC: Effect of an inhibitor of DNA methylation on T cells. II. 5-Azacytidine induces self-reactivity in antigen-specific T4+ cells. Hum Immunol 17:456-470, 1986

2. Richardson BC, Liebling MR, Hudson JL: CD4+ cells treated with DNA methylation inhibitors induce autologous B cell differentiation. Clin Immunol Immunopathol 55:368-381, 1990

3. Richardson BC, Kahn L, Lovett EJ, Hudson J: Effect of an inhibitor of DNA methylation on T cells. I. 5-Azacytidine induces $\mathrm{T} 4$ expression on $\mathrm{T} 8+\mathrm{T}$ cells. J Immunol 137:35-39, 1986

4. Jones PA: Gene activation by azacytidine, DNA Methylation. Edited by A Razin, H Cedar, AD Riggs. New York, Springer Verlag, 1984

5. Doerfler W: DNA methylation and gene activity. Annu Rev Biochem 52:93-124, 1983

6. Quddus J, Gavalchin J, Johnson K, Richardson B: T cells made autoreactive with 5 -azacytidine induce lupus in syngeneic mice. Submitted

7. Cornacchia E, Golbus J, Maybaum J, Strahler J, Hanash $S$, Richardson BC: Hydralazine and procainamide inhibit T cell DNA methylation and induce autoreactivity. J Immunol 140:2197-2200, 1988

8. Richardson B, Scheinbart L, Strahler J, Gross L, Hanash $\mathrm{S}$, Johnson M: Evidence for impaired T cell DNA methylation in systemic lupus erythematosus and rheumatoid arthritis. Arthritis Rheum 33:1665-1673, 1990

9. Arnett FC, Edworthy SM, Bloch DA, McShane DJ, Fries JF, Cooper NS, Healey LA, Kaplan SR, Liang MH, Luthra HS, Medsger TA Jr, Mitchell DM, Neustadt DH, Pinals RS, Schaller JG, Sharp JT, Wilder RL, Hunder GG: The American Rheumatism Association 1987 revised criteria for the classification of rheumatoid arthritis. Arthritis Rheum 31:315-324, 1988

10. Tan EM, Cohen AS, Fries JF, Masi AT, McShane DJ, Rothfield NF, Schaller JG, Talal N, Winchester RJ: The 1982 revised criteria for the classification of systemic lupus erythematosus. Arthritis Rheum 25:1271-1277, 1982

11 Subcommittee for Scleroderma Criteria of the American Rheumatism Association Diagnostic and Therapeutic Criteria Committee: Preliminary criteria for the classification of systemic sclerosis (scleroderma). Arthritis Rheum 23:581-590, 1980

12. Bohan A, Peter JB: Polymyositis and dermatomyositis. N Engl J Med 292:344-347, 1975

13. Barada FA Jr, Andrews BS, Davis JS IV, Taylor RP: Antibodies to $\mathrm{Sm}$ in patients with systemic lupus erythematosus: correlation of $\mathrm{Sm}$ antibody titers with disease activity and other laboratory parameters. Arthritis Rheum 24:1236-1244, 1981

14. Pinals RS, Masi AT, Larsen RA, and The Subcommittee for Criteria of Remission in Rheumatoid Arthritis of the American Rheumatism Association Diagnostic and Therapeutic Criteria Committee: Preliminary criteria for clinical remission in rheumatoid arthritis. Arthritis Rheum 24:1308-1315, 1981

15. Swanson JW: Multiple sclerosis: update in diagnosis and review of prognostic factors. Mayo Clin Proc 64:577586,1989

16. Golbus J, Salata M, Greenwood J, Hudson J, Richardson BC: Increased immunoglobulin response to $\gamma$-interferon by lymphocytes from patients with systemic lupus erythematosus. Clin Immunol Immunopathol 46:129140,1988

17. Salata M, Golbus J, Richardson BC: Diminished response to an inhibitory signal in lymphocytes from patients with systemic lupus erythematosus. Clin Exp Immunol 71:439-444, 1988

18. Rabin H, Hopkins RF III, Ruscetti FW, Neubauer RH, Brown RL, Kawakami TG: Spontaneous release of a factor with properties of $T$ cell growth factor from a continuous line of primate tumor $\mathrm{T}$ cells. J Immunol 127:1852-1856, 1981

19. Sanchez-Madrid F, Krensky AM, Ware CF, Robbins E, Strominger JL, Burakoff SJ, Springer TA: Three distinct antigens associated with human T-lymphocyte-mediated cytolysis: LFA-1, LFA-2, and LFA-3. Proc Natl Acad Sci USA 79:7489-7493, 1982

20. Rothlein R, Dustin ML, Marlin SD, Springer TA: A 
human intercellular adhesion molecule (ICAM-1) distinct from LFA-1. J Immunol 137:1270-1274, 1986

21. LeBien T, Bradley JG, Koller B: Preliminary structural characterization of the leukocyte cell surface molecule recognized by monoclonal antibody TA-1. J Immunol 130:1833-1836, 1983

22. Shimizu Y, van Seventer GA, Siraganian R, Wahl L, Shaw S: Dual role of the CD44 molecule in T cell adhesion and activation. J Immunol 143:2457-2463, 1989

23. Braylan RC, Benson NA, Nourse V, Kruth HS: Correlated analysis of cellular DNA, membrane antigens and light scatter of human lymphoid cells. Cytometry 2:337343,1982

24. Ottenhoff THM, Ab BK, van Embden JDA, Thole JER, Kiessling R: The recombinant $65-\mathrm{kD}$ heat shock protein of Mycobacterium bovis bacillus Calmette-Guerin/M. tuberculosis is a target molecule for $\mathrm{CD}^{+}$cytotoxic $\mathrm{T}$ lymphocytes that lyse human monocytes. J Exp Med 168:1947-1952, 1988

25. Todd RF, Meuer SC, Romain PL, Schlossman SF: A monoclonal antibody that blocks class II histocompatibility-related immune interactions. Hum Immunol 10: 23-40, 1984

26. Kessler SW: Use of protein A-bearing staphylococci for the immunoprecipitation and isolation of antigens from cells. Methods Enzymol 73:442-459, 1981

27. Hanash SM, Baier JL, McCurry L, Schwartz SA: Lineage-related polypeptide markers in acute lymphoblastic leukemia detected by two-dimensional gel electrophoresis. Proc Natl Acad Sci USA 83:807-811, 1986

28. Hanash S, Chu EHY, Kuick R, Skolnick M, Neel J, Strahler J, Pivirotto TS, Niezgoda W: Detection of human somatic cell structural gene mutations by twodimensional electrophoresis. Struct Funct Genet 2:1319,1987

29. Weiss A, Newton M, Crommie D: Expression of T3 in association with a molecule distinct from the T-cell antigen receptor heterodimer. Proc Natl Acad Sci USA 83:6998-7002, 1986

30. MacDonald RJ, Swift GH, Przybyla AE, Chirgwin JM: Isolation of RNA using guanidium salts. Methods Enzymol 152:219-227, 1987

31. Seed B, Aruffo A: Molecular cloning of the CD2 antigen, the T-cell erythrocyte receptor, by a rapid immunoselection procedure. Proc Natl Acad Sci USA 84:33653369,1987

32. Chan KK, Giannini DD, Staroscik JA, Sadee W: 5-Azacytidine hydrolysis kinetics measured by high-pressure liquid chromatography and ${ }^{13} \mathrm{C}$-NMR spectroscopy. J Pharm Sci 68:807-812, 1979

33. Marlin SD, Springer TA: Purified intercellular adhesion molecule-1 (ICAM-1) is a ligand for lymphocyte function-associated antigen 1 (LFA-1). Cell 51:813-819, 1987

34. Biddison WE, Rao PE, Talle MA, Goldstein G, Shaw S: Possible involvement of the T4 molecule in $T$ cell recognition of class II HLA antigens: evidence from studies of proliferative responses to SB antigens. J Exp Med 156:1065-1076, 1982

35. Yu DTY, McCune JM, Fu SM, Winchester RJ, Kunkel HG: Two types of Ia-positive T cells: synthesis and exchange of Ia antigens. J Exp Med 152:89-98, 1980

36. Mentzer SJ, Faller DV, Burakoff SJ: Interferon- $\gamma$ induction of LFA-1-mediated homotypic adhesion of human monocytes. J Immunol 137:108-113, 1986

37. Taylor SM, Jones PA: Multiple new phenotypes induced in 10T1/2 and 3T3 cells treated with 5-azacytidine. Cell 17:771-779, 1979

38. Sanders ME, Makgoba MW, Sharrow SO, Stephany D, Springer TA, Young HA, Shaw S: Human memory T lymphocytes express increased levels of three cell adhesion molecules (LFA-3, CD2, and LFA-1) and three other molecules (UCHL1, CDw29, and Pgp-1) and have enhanced IFN- $\gamma$ production. J Immunol 140:1401-1407, 1988

39. Nyce J, Liu L, Jones PA: Variable effects of DNAsynthesis inhibitors upon DNA methylation in mammalian cells. Nucleic Acids Res 14:4353-4366, 1986

40. Altmann DM, Hogg N, Trowsdale J, Wilkinson D: Cotransfection of ICAM-1 and HLA-DR reconstitutes human antigen-presenting cell function in mouse $\mathrm{L}$ cells. Nature 338:512-514, 1989

41. Lakhanpal S, Handwerger BS: Interleukin 2 receptors and responsiveness to recombinant human interleukin 2 in patients with systemic lupus erythematosus. Mayo Clin Proc 62:3-7, 1987

42. Yocum DE, Wilder RL, Dougherty S, Klippel JH, Pillemer S, Wahl S: Immunologic parameters of response in patients with rheumatoid arthritis treated with cyclosporin A. Arthritis Rheum 33:1310-1316, 1990

43. Silver RM, Redelman D, Zvaifler NJ: Studies of rheumatoid synovial fluid lymphocytes. Clin Immunol Immunopathol 27:15-27, 1983

44. Erb P, Grogg D, Troxler M, Kennedy M, Fluri M: CD4 ${ }^{+}$ $T$ cell-mediated killing of MHC class II-positive antigenpresenting cells. J Immunol 144:790-795, 1990

45. Ju ST, DeKruyff RH, Dorf ME: Inducer T-cell-mediated killing of antigen-presenting cells. Cell Immunol 101: 613-624, 1986

46. Kaufmann SHE, Hug E, Vath U, DeLibero G: Specific lysis of Listeria monocytogenes-infected macrophages by class II-restricted L3T4 + T cells. Eur J Immunol 17:237-246, 1987

47. Ottenhoff THM, Mutis $T$ : Specific killing of cytotoxic $T$ cells and antigen-presenting cells by $\mathrm{CD}^{+}$cytotoxic $\mathrm{T}$ cell clones. J Exp Med 171:2011-2024, 1990

48. Rosenkrantz K, Dupont B, Williams D, Flomenberg N: Autocytotoxic and autosuppressor T-cell lines generated from autologous lymphocyte cultures. Hum Immunol 19:189-203, 1987 
49. Miller KB, Schwartz RS: Familial abnormalities of suppressor-cell function in systemic lupus erythematosus. N Engl J Med 301:803-809, 1979

50. Linker-Israeli M, Quismorio FP Jr, Horwitz DA: CD8+ lymphocytes from patients with systemic lupus erythematosus sustain, rather than suppress, spontaneous polyclonal IgG production and synergize with $\mathrm{CD} 4+$ cells to support autoantibody synthesis. Arthritis Rheum 33:1216-1225, 1990

51. Frank MM, Hamburger MI, Lawley TJ, Kimberly RP,
Plotz PH: Defective reticuloendothelial system Fcreceptor function in systemic lupus erythematosus. $\mathbf{N}$ Engl J Med 300:518-523, 1979

52. Decker JL: Systemic lupus erythematosus: evolving concepts. Ann Intern Med 91:587-604, 1979

53. Yoshida H, Yoshida M, Merino R, Shibata T, Izui S: 5-Azacytidine inhibits the lpr gene-induced lymphadenopathy and acceleration of lupus-like syndrome in MRL/MpJ-lpr/lpr mice. Eur J Immunol 20:1989-1993, 1990 